\title{
Worldwide biogeography of Symbiodinium in tropical octocorals
}

\author{
Tamar L. Goulet ${ }^{1, *}$, Christopher Simmons ${ }^{2}$, Denis Goulet ${ }^{1}$ \\ ${ }^{1}$ Department of Biology and ${ }^{2}$ Department of Sociology and Anthropology, University of Mississippi, University, \\ Mississippi 38677, USA
}

\begin{abstract}
Although octocorals are important components of coral reefs, most research on the genetic diversity of symbiotic zooxanthellae (Symbiodinium spp.) has focused on scleractinian (stony) corals. For both groups, most geographic comparisons have occurred within the same ocean or only included a few geographic sites. We characterized the genetic diversity of Symbiodinium in tropical octocorals in 15 geographic areas throughout the world. By combining octocoral samples analyzed in this study with published data, the cladal identities of zooxanthellae in 117 octocoral species were identified and a global analysis was performed. For 63 octocoral species, the Symbiodinium type was also identified. The vast majority $(87.2 \%)$ of octocorals hosted a single zooxanthella clade. Most octocorals also hosted specific Symbiodinium types. A biogeographic pattern emerged. Octocorals from 4 geographic areas in the Indo-west Pacific hosted Symbiodinium C. In the Great Barrier Reef, 11 octocoral species (24.4\%) hosted Symbiodinium D, 3 species hosted Symbiodinium G, and 1 species each hosted Symbiodinium A and B. Red Sea octocorals hosted predominantly Symbiodinium C, with Symbiodinium A occurring in 3 species. In Hawaii, 2 octocorals hosted Symbiodinium C and 1 hosted Symbiodinium A. In Bermuda, only clade B was found. In the Caribbean, unlike in the Indo-Pacific, the dominant Symbiodinium was B, predominantly type B1, with Symbiodinium C occurring in a few species. Understanding the similarities and differences between octocoral and scleractinian coral symbioses with zooxanthellae may enable predictions of which symbioses will survive in periods of environmental change.
\end{abstract}

KEY WORDS: Symbiodinium • Zooxanthellae · Octocorals · Corals · GIS · Clade · RFLP · Biogeography Resale or republication not permitted without written consent of the publisher

\section{INTRODUCTION}

On coral reefs, the mutualism between cnidarians (e.g. octocorals, corals, sea anemones) and their symbiotic dinoflagellates (zooxanthellae) creates the framework of the ecosystem. To address ecological and evolutionary questions concerning these symbioses, it is imperative to first identify the partners involved. Zooxanthella identification in the past was hindered by the lack of distinguishing morphological characteristics. Several time-consuming techniques, requiring a great deal of expertise, were employed for algal identification. Examples include culturing and/or identifying zooxanthellae based on their motile form (Trench 1997) and using antigenic features (Kinzie \& Chee 1982) and cell architecture (Blank 1987). These techniques lead to the differentiation of only a small number of Symbiodinium species.

Knowledge of the diversification and classification of zooxanthellae has grown tremendously since the initial application of molecular techniques (Rowan \& Powers 1991a). Based on sequence comparison of small (ssRNA) and large (lsRNA) subunit ribosomal RNA, zooxanthellae are currently divided into 8 clades (reviewed by Pochon et al. 2006, Stat et al. 2006) although Tchernov et al. (2004) distinguished between 13 clades based on genetic distance. Each clade includes multiple zooxanthella species (Rowan 1998). 
Studies of other DNA regions such as internal transcribed spacer (ITS) regions of nuclear DNA (Baillie et al. 2000, LaJeunesse 2001, van Oppen et al. 2001), the 23S rDNA of chloroplasts (Santos et al. 2002, Pochon et al. 2006), psbA minicircle (Barbrook et al. 2006), mitochondrial sequences (Takabayashi et al. 2004), and microsatellites (Santos et al. 2004, Magalon et al. 2006) support the cladal relationships based on ssRNA and lsRNA and provide within-clade resolution. Most reports have identified Symbiodinium at the clade level.

Within-clade comparison of zooxanthellae is complicated by the fact that researchers, using different parts of the genome for the within-clade division, create their own nomenclature with minimal cross-reference to other sub-cladal nomenclature (LaJeunesse 2001, van Oppen et al. 2001, Santos et al. 2003a). Consequently, a single within-clade nomenclature does not exist, and 2 identities can be given to the same zooxanthella type. For example, Symbiodinium named B1 (LaJeunesse 2002) is equivalent to B184 (Kirk et al. 2005). In addition, prior to within-clade classification, it is important to initially compare hosts and distinguish zooxanthellae at the clade level.

One can ask questions about zooxanthellae from the individual symbiont level (Goulet \& Coffroth 2003a,b), the symbiont population level (e.g. Santos et al. 2003b, Magalon et al. 2006), the broad clade level, and all levels in between, with each level providing important information about the symbioses. Clade-level comparisons are informative. For example, comparisons of Symbiodinium clades within cnidarian species have been used to elucidate between- and within-species biogeographic patterns (LaJeunesse \& Trench 2000, Loh et al. 2001, Rodriguez-Lanetty et al. 2001, Baker 2003) and intraspecific physiological differences (Little et al. 2004, Rowan 2004, Goulet et al. 2005, Berkelmans \& van Oppen 2006, LaJeunesse et al. 2007). Since this study is a broad geographic study, the clade level is the most appropriate level for comparison. Furthermore, cladal distinction allows comparison to previously published studies.

Most studies characterizing the genetic identity of zooxanthellae have concentrated on scleractinian corals (reviewed by Baker 2003, Stat et al. 2006), even though octocorals are major components of the benthos on many reefs (Goldberg 1973, Kinzie 1973, 1974, Muzik 1982, Lasker \& Coffroth 1983, Sánchez et al. 1997, 2003, Fabricius \& Alderslade 2001). Research determining zooxanthella clade identity in octocorals has focused on juveniles (Coffroth et al. 2001) or on a few octocoral species and/or one geographic area (Rowan \& Powers 1991a, LaJeunesse 2001, 2002, Santos et al. 2001, 2002, 2003b, 2004, Goulet \& Coffroth 2003a,b, Barneah et al. 2004). One study sampled mul- tiple geographic locations in the Caribbean, reporting on zooxanthella clades in 35 octocoral species (Goulet \& Coffroth 2004).

Biogeographic studies of zooxanthella clades in scleractinian corals, octocorals, or zoanthids have predominantly compared different sites within the same ocean (Loh et al. 2001, Rodriguez-Lanetty et al. 2001, Burnett 2002, Rodriguez-Lanetty \& Hoegh-Guldberg 2003, Goulet \& Coffroth 2004). Three studies compared zooxanthella clades in hosts from 1 site in the Caribbean versus the Great Barrier Reef in the Indo-west Pacific; 2 of these studies were on scleractinian corals (Baker \& Rowan 1997, LaJeunesse et al. 2003) and 1 on 34 species of zooxanthellate octocorals (van Oppen et al. 2005). The objective of this study was to perform a comprehensive worldwide biogeographic comparison of Symbiodinium clades in tropical octocorals.

\section{MATERIALS AND METHODS}

Sampling scheme. We identified zooxanthella clades in octocoral species that were collected from various locations throughout the tropics (reference 1 in Table 1). Our data were combined with those reported in the literature for a total data set of 117 octocoral species (Table 1). Since samples were collected while surveying the reefs, sample sizes varied. The combined data set included samples from numerous reef sites from 15 geographic locations that were identified according to the country or location: Australia, Bahamas, Barbados, Belize, Bermuda, Fiji, Florida Keys, Guam, Hawaii, Israel, Japan, Mexico, Panama, Dry Tortugas, and US Virgin Islands (Table 2). These geographic locations were in the Atlantic, Caribbean, Pacific, Red Sea, and Indo-west Pacific.

For each octocoral that we sampled, $6 \mathrm{~cm}$ of octocoral tissue was removed from the tip in branching species, or an equivalent amount of tissue from encrusting forms. Tissue samples were preserved in $1.5 \mathrm{ml}$ micro centrifuge tubes in $95 \%$ ethanol. We used $0.5 \times 0.5 \mathrm{~cm}$ of octocoral tissue for DNA extraction.

DNA analysis. DNA was extracted from each piece of tissue using a phenol chloroform protocol as described by Goulet \& Coffroth (2003a). We amplified the ssRNA with a 'universal' primer (ss5) and a zooxanthella-biased primer, ss3Z (Rowan \& Powers 1991b) following the protocol described by Goulet \& Coffroth (2003a). We digested the resulting PCR product with the restriction enzymes TaqI (MBI Fermentas) and DpnII (New England Biolabs). We ran the product on a $2 \%$ w/v agarose (Eastman Kodak) gel, which was stained with ethidium bromide for UV visualization. RFLP genotypes of cloned ssRNA genes were run as standards on each gel, in addition to 100 bp ladders. 
Table 1. Identity of Symbiodinium clades in 117 host octocoral species sampled throughout the tropics. Symbiodinium type is based on the nomenclature of LaJeunnesse (2001). Au: Australia, Ba: Bahamas, Bb: Barbados, Be: Bermuda, Bz: Belize, Fj: Fiji, Fl: Florida Keys, Gu: Guam, Ha: Hawaii, Is: Israel, Ja: Japan, Me: Mexico, Pa: Panama, To: Dry Tortugas, VI: US Virgin Islands. Clades or types co-occurring in the same colony are denoted with the symbol ' $\&$ '. $(\mathrm{N})$ : number of colonies sampled at each location; N: total number of colonies sampled for each octocoral species

\begin{tabular}{|c|c|c|c|c|c|c|c|}
\hline \multirow{2}{*}{ Family } & \multirow{2}{*}{$\begin{array}{l}\text { - Octocoral host - } \\
\text { Genus }\end{array}$} & \multirow[b]{2}{*}{ Species } & \multicolumn{2}{|c|}{ Zooxanthella } & \multirow{2}{*}{$\begin{array}{l}\text { Location } \\
(\mathrm{N})\end{array}$} & \multirow[t]{2}{*}{$\mathrm{N}$} & \multirow[t]{2}{*}{ Source } \\
\hline & & & Clade & 'Type' & & & \\
\hline \multirow[t]{23}{*}{ Alcyoniidae } & \multirow[t]{3}{*}{ Cladiella } & pachyclados & $\mathrm{C}$ & & Is & 3 & 11 \\
\hline & & tuberculoides & $\mathrm{C}$ & & Is & 3 & 11 \\
\hline & & spp. & $\mathrm{C}, \mathrm{D}$ & & $\mathrm{Au}(2), \mathrm{Fj}(1)$ & 3 & 1,18 \\
\hline & Klyxum & spp. & $\mathrm{C}, \mathrm{D}$ & $\mathrm{C} 64$ & $\mathrm{Au}$ & 3 & 12,18 \\
\hline & \multirow[t]{2}{*}{ Lobophytum } & compactum & $\mathrm{C}$ & $\mathrm{C} 1: 3 \mathrm{a}$ & $\mathrm{Au}$ & 7 & 3 \\
\hline & & spp. & $\mathrm{C}$ & $\mathrm{C} 1, \mathrm{C} 3 \mathrm{j}$ & $\begin{array}{l}\mathrm{Au}(12), \mathrm{Fj}(4), \\
\mathrm{Gu}(1)\end{array}$ & 17 & $\begin{array}{c}1,8 \\
12,18\end{array}$ \\
\hline & \multirow[t]{2}{*}{ Rhytisma } & fulvum fulvum & $\mathrm{C}$ & & $\mathrm{Au}(2)$, Is (18) & 20 & 1,11 \\
\hline & & spp. & $\mathrm{C}$ & $\mathrm{C} 1, \mathrm{C} 1: 1$ & $\mathrm{Au}$ & 3 & 3,18 \\
\hline & \multirow[t]{4}{*}{ Sarcophyton } & ehrenbergi & $\mathrm{C}$ & & $\mathrm{Au}$ & 1 & 17 \\
\hline & & glaucum & $\mathrm{C}$ & & $\mathrm{Gu}(4)$, Is (4) & 8 & 1,11 \\
\hline & & trocheliophorum & $\mathrm{C}$ & & $\mathrm{Gu}$ (5), Is (5) & 10 & 1,11 \\
\hline & & spp. & $\mathrm{C}$ & $\begin{array}{l}\text { C1, C1:3a, C3j, } \\
\text { C65, C71a }\end{array}$ & $\begin{array}{l}\mathrm{Au}(26), \mathrm{Fj}(6), \\
\mathrm{Ja}(1)\end{array}$ & 33 & $\begin{array}{l}1,3,8 \\
12,18\end{array}$ \\
\hline & \multirow[t]{11}{*}{ Sinularia } & abrupta & $\mathrm{C}$ & & На & 7 & 1 \\
\hline & & erecta & $\mathrm{C}$ & & $\mathrm{Fj}$ & 3 & 1 \\
\hline & & flexibilis & $\mathrm{C}$ & $\mathrm{C} 1: 3 \mathrm{a}$ & $\mathrm{Au}$ & 8 & 3 \\
\hline & & gardineri & $\mathrm{C}$ & & Is & 3 & 11 \\
\hline & & gyrosa & $\mathrm{C}$ & & $\mathrm{Fj}$ & 3 & 1 \\
\hline & & leptoclados & $\mathrm{C}$ & & Is & 3 & 11 \\
\hline & & lochmodes & $\mathrm{C}$ & & $\mathrm{Ja}$ & 1 & 17 \\
\hline & & maxima & $\mathrm{C}$ & & $\mathrm{Gu}$ & 1 & 1 \\
\hline & & polydactyla & $\mathrm{C}$ & $\mathrm{C} 1: 3 \mathrm{a}$ & $\begin{array}{l}\mathrm{Au}(6), \mathrm{Gu}(2) \text {, } \\
\text { Is (3) }\end{array}$ & 11 & $1,3,11$ \\
\hline & & querciformis & $\mathrm{C}$ & & Fj (6), Is (3) & 9 & 1,11 \\
\hline & & spp. & $\mathrm{C}$ & C1, C1c, C3j, C65 & $\begin{array}{c}\mathrm{Au}(18), \mathrm{Fj}(14) \\
\mathrm{Gu}(4), \mathrm{Ja}(1)\end{array}$ & 37 & $\begin{array}{c}1,8,9,12 \\
17,18\end{array}$ \\
\hline \multirow[t]{3}{*}{ Anthothelidae } & Alertigorgia & orientalis & $\mathrm{C}, \mathrm{D}$ & & $\mathrm{Au}$ & 2 & 18 \\
\hline & Erythropodium & caribaeorum & $\mathrm{B}, \mathrm{C}$ & $\mathrm{B} 1, \mathrm{C} 1, \mathrm{C} 3$ & $\begin{array}{l}\mathrm{Bb}(8), \mathrm{Bz}(5) \\
\mathrm{Me}(1), \mathrm{Pa}(21)\end{array}$ & 35 & $2,7,21$ \\
\hline & Icilogoria & sp. & $\mathrm{C}$ & $\mathrm{C} 1$ & $\mathrm{Au}$ & 1 & 12 \\
\hline \multirow[t]{4}{*}{ Briareidae } & \multirow[t]{4}{*}{ Briareum } & asbestinum & $\mathrm{B}, \mathrm{C}$ & $\begin{array}{l}\text { B1, B2, B19, } \\
\text { B19a, B33, C1 }\end{array}$ & $\begin{array}{l}\mathrm{Ba}(4), \mathrm{Bb}(2), \\
\mathrm{Bz}(4), \mathrm{Fl}(38), \\
\mathrm{Me}(1), \mathrm{Pa}(38), \\
\text { To (8), VI (3) }\end{array}$ & 98 & $\begin{array}{l}2,6 \\
9,18 \\
19,21\end{array}$ \\
\hline & & stechei & $\mathrm{D}$ & & $\mathrm{Au}$ & 2 & 18 \\
\hline & & violacea & $\mathrm{C}$ & & $\mathrm{Au}$ & 2 & 18 \\
\hline & & spp. & $\mathrm{C}$ & $\begin{array}{c}\text { C1, C1:1 } \\
\mathrm{C} 1: 2, \mathrm{C} 3, \mathrm{C} 23\end{array}$ & $\mathrm{Au}$ & 22 & $\begin{array}{c}1,3,8 \\
12\end{array}$ \\
\hline \multirow[t]{2}{*}{ Clavularidae } & \multirow[t]{2}{*}{ Clavularia } & koellikeri & $\mathrm{D}$ & D3 & $\mathrm{Au}$ & 6 & 3 \\
\hline & & $\mathrm{sp}$ & $\mathrm{D}$ & D3 & $\mathrm{Au}$ & 4 & 12,18 \\
\hline \multirow[t]{2}{*}{ Ellisellidae } & \multirow[t]{2}{*}{ Junceella } & fragilis & G & & $\mathrm{Au}$ & 3 & 18 \\
\hline & & spp. & $\mathrm{C}$ & & $\mathrm{Au}(2), \mathrm{Gu}(1)$ & 3 & 1 \\
\hline \multirow[t]{5}{*}{ Gorgoniidae } & \multirow[t]{4}{*}{ Gorgonia } & flabellum & B & B1 & $\begin{array}{c}\mathrm{Bb}(1), \mathrm{Me}(1), \\
\mathrm{Pa}(4), \mathrm{VI}(1)\end{array}$ & 7 & $\begin{array}{c}2,7,14 \\
19,21\end{array}$ \\
\hline & & mariae & B & B1 & $\begin{array}{l}\mathrm{Ba}(1), \mathrm{Bb}(2), \\
\mathrm{Me}(2), \mathrm{Pa}(4)\end{array}$ & 9 & $\begin{array}{c}2,7 \\
18,21\end{array}$ \\
\hline & & ventalina & B & B1 & $\begin{array}{l}\mathrm{Bb}(3), \mathrm{FL}(48), \\
\mathrm{Me}(1), \mathrm{Pa}(3)\end{array}$ & 55 & $\begin{array}{l}2,15 \\
16,21\end{array}$ \\
\hline & & spp. & B & B1 & $\begin{array}{l}\mathrm{Ba}(1), \mathrm{Fl}(11), \\
\mathrm{Pa}(1)\end{array}$ & 13 & $\begin{array}{c}2,6,9 \\
14\end{array}$ \\
\hline & Hicksonella & expansa & $\mathrm{C}$ & C65 & $\mathrm{Au}$ & 1 & 12 \\
\hline
\end{tabular}


Table 1. (continued)

\begin{tabular}{|c|c|c|c|c|c|c|c|}
\hline \multirow{2}{*}{ Family } & \multicolumn{2}{|l|}{ - Octocoral host } & \multicolumn{2}{|c|}{ Zooxanthella } & \multirow{2}{*}{$\begin{array}{l}\text { Location } \\
(\mathrm{N})\end{array}$} & \multirow{2}{*}{$\mathrm{N}$} & \multirow{2}{*}{ Source } \\
\hline & Genus & Species & Clade & ‘Type' & & & \\
\hline Gorgoniidae & Leptogorgia & sp. & B & & $\mathrm{Fl}$ & 2 & 14 \\
\hline \multirow[t]{15}{*}{ (continued) } & Pinnigorgia & flava & $\mathrm{C}$ & $\mathrm{C} 1: 1 \& \mathrm{C} 1: 2$ & $\mathrm{Au}$ & 2 & 3 \\
\hline & \multirow{4}{*}{ Plexaurella } & dichotoma & $\mathrm{C}$ & & $\mathrm{Me}(2), \mathrm{Pa}(2)$ & 4 & 2,18 \\
\hline & & grisea & $\mathrm{B}, \mathrm{C}$ & & $\mathrm{Me}(1), \mathrm{Pa}(1)$ & 2 & 2,18 \\
\hline & & nutans & $\mathrm{B}, \mathrm{C}$ & B1, B1a & $\begin{array}{l}\mathrm{Ba}(1), \mathrm{Bb}(1) \\
\mathrm{Me}(2), \mathrm{Pa}(3)\end{array}$ & 7 & $\begin{array}{c}2,7,18 \\
21\end{array}$ \\
\hline & & sp. & $\mathrm{B}, \mathrm{C}$ & $\mathrm{B} 1, \mathrm{~B} 1 \mathrm{~L}, \mathrm{C} 2 \mathrm{r}$ & $\begin{array}{c}\mathrm{Bb}(2), \mathrm{Fl}(4) \\
\mathrm{Pa}(2), \mathrm{VI}(1)\end{array}$ & 9 & $2,14,21$ \\
\hline & \multirow[t]{7}{*}{ Pseudopterogorgia } & acerosa & B & B1 & $\mathrm{Fl}$ & 2 & 9 \\
\hline & & americana & B & B1, B1i & $\begin{array}{c}\mathrm{Bb}(3), \mathrm{Bz}(2) \\
\mathrm{Fl}(10), \mathrm{Me}(2)\end{array}$ & 17 & $\begin{array}{c}2,6,7 \\
9,21\end{array}$ \\
\hline & & bipinnata & B & B1 & $\begin{array}{l}\text { Ba (93),Pa (2), } \\
\text { VI (1) }\end{array}$ & 96 & $2,15,21$ \\
\hline & & elisabethae & B & B1 & $\mathrm{Ba}$ & 767 & $\begin{array}{l}2,6,9 \\
10,15\end{array}$ \\
\hline & & kallos & B & B1 & $\mathrm{Me}$ & 1 & 7 \\
\hline & & rigida & B & B1 & $\mathrm{Me}$ & 1 & 7 \\
\hline & & sp. & B & $\mathrm{B} 1$ & $\mathrm{Bb}$ & 4 & 21 \\
\hline & \multirow[t]{2}{*}{ Pterogorgia } & anceps & $\mathrm{B}$ & B1 & $\mathrm{Me}(2), \mathrm{Pa}(4)$ & 6 & $2,7,18$ \\
\hline & & citrina & B & $\mathrm{B} 1, \mathrm{~B} 1 \mathrm{~m}$ & $\begin{array}{l}\mathrm{Bb}(1), \mathrm{Me}(1), \\
\text { VI (1) }\end{array}$ & 3 & 18,21 \\
\hline & Rumphella & spp. & $\mathrm{C}$ & $\mathrm{C} 1$ & $\mathrm{Au}$ & 2 & 12,18 \\
\hline Helioporidae & Heliopora & coerulea & $\mathrm{C}$ & $\mathrm{C} 1$ & $\mathrm{Au}$ & 5 & 12,18 \\
\hline \multirow[t]{2}{*}{ Ifalukellidae } & \multirow[t]{2}{*}{ Plumigorgia } & schoboti & $\mathrm{C}$ & & $\mathrm{Au}$ & 1 & 18 \\
\hline & & sp. & $\mathrm{C}$ & $\mathrm{C} 1$ & $\mathrm{Au}$ & 1 & 12 \\
\hline \multirow[t]{2}{*}{ Isididae } & \multirow[t]{2}{*}{ Isis } & hippuris & $\mathrm{D}$ & & $\mathrm{Au}$ & 1 & 18 \\
\hline & & spp. & $\mathrm{C}$ & $\mathrm{C} 3, \mathrm{C} 23$ & $\mathrm{Au}$ & 2 & 8,12 \\
\hline Metithaedae & Asterionella & sp. & $\mathrm{C}$ & & $\mathrm{Gu}$ & 4 & 1 \\
\hline \multirow[t]{11}{*}{ Nephtheidae } & \multirow[t]{2}{*}{ Capnella } & lacerthliensis & $\mathrm{C}$ & & $\mathrm{Au}$ & 2 & 1 \\
\hline & & spp. & $\mathrm{A}, \mathrm{C}, \mathrm{D}$ & & $\mathrm{Au}$ & 2 & 18 \\
\hline & Lemnalia & spp. & $\mathrm{C}$ & $\mathrm{C} 1: 2$ & $\mathrm{Au}(4)$, Is (5) & 9 & $1,3,18$ \\
\hline & Litophyton & arboreum & $\mathrm{A}$ & & Is & 10 & 1,11 \\
\hline & Nephthea & spp. & $\mathrm{A}, \mathrm{B}, \mathrm{C}, \mathrm{D}$ & $\begin{array}{l}\text { B1, B1n, B36, } \\
\text { C1, C1:2,D1a }\end{array}$ & $\mathrm{Au}(8)$, Is (3) & 11 & $3,8,11$ \\
\hline & \multirow[t]{4}{*}{ Paralemnalia } & digitiformis & $\mathrm{C}$ & $\mathrm{C} 1: 2, \mathrm{C} 64$ & $\mathrm{Au}$ & 3 & 3 \\
\hline & & eburnea & $\mathrm{C}$ & & Is & 3 & 11 \\
\hline & & thyrsoidea & $\mathrm{C}$ & $\mathrm{C} 1: 2$ & $\mathrm{Au}(4)$, Is (3) & 7 & 3,11 \\
\hline & & spp. & $\mathrm{C}$ & & $\mathrm{Au}$ & 2 & 18 \\
\hline & \multirow[t]{2}{*}{ Stereonephthya } & cundabiluensis & $\mathrm{A}$ & A9 & Is & 6 & 11,20 \\
\hline & & spp. & $\mathrm{C}, \mathrm{G}$ & $\mathrm{C} 15$ & $\mathrm{Au}(2), \mathrm{Fj}(3)$ & 5 & $1,3,18$ \\
\hline \multirow[t]{12}{*}{ Plexauridae } & \multirow[t]{12}{*}{ Eunicea } & asperula & B & & $\mathrm{Me}(1), \mathrm{Pa}(1)$ & 2 & 2,18 \\
\hline & & calyculata & $\mathrm{B}$ & & $\mathrm{Me}$ & 1 & 18 \\
\hline & & clavigera & $\mathrm{B} \& \mathrm{C}$ & $\mathrm{B} 1, \mathrm{C} 1$ & $\mathrm{Me}$ & 2 & 7 \\
\hline & & colombiensis & B & & $\mathrm{Pa}$ & 2 & 2 \\
\hline & & fusca & B & & $\mathrm{Pa}$ & 1 & 2 \\
\hline & & laciniata & B & B1 & $\mathrm{Me}(2), \mathrm{Pa}(5)$ & 7 & $2,7,18$ \\
\hline & & mammosa & B & B1, B9 & $\begin{array}{l}\text { Ba (2), Me (1), } \\
\text { Pa (7) }\end{array}$ & 10 & 2,7 \\
\hline & & pallida & B & & $\mathrm{Pa}$ & 1 & 2 \\
\hline & & succinea & B & & $\mathrm{Me}$ & 2 & 18 \\
\hline & & tayrona & B & & $\mathrm{Pa}$ & 2 & 2 \\
\hline & & tourneforti & $\mathrm{B}, \mathrm{C}, \mathrm{B} \& \mathrm{C}$ & B1, C1 & $\begin{array}{l}\mathrm{Ba}(1), \mathrm{Be}(1), \\
\mathrm{Me}(3), \mathrm{Pa}(5)\end{array}$ & 10 & $\begin{array}{c}1,2,7 \\
18\end{array}$ \\
\hline & & spp. & B & B1 & $\begin{array}{c}\mathrm{Ba}(3), \mathrm{Fl}(14), \\
\mathrm{Me}(2), \mathrm{Pa}(4)\end{array}$ & 23 & $\begin{array}{c}2,6,9 \\
18,14\end{array}$ \\
\hline
\end{tabular}


Table 1. (continued)

\begin{tabular}{|c|c|c|c|c|c|c|c|}
\hline \multirow{2}{*}{ Family } & \multirow{2}{*}{$\begin{array}{l}\text { Octocoral host } \\
\text { Genus }\end{array}$} & \multirow[b]{2}{*}{ Species } & \multicolumn{2}{|c|}{ Zooxanthella } & \multirow{2}{*}{$\begin{array}{l}\text { Location } \\
\text { (N) }\end{array}$} & \multirow[t]{2}{*}{$\mathrm{N}$} & \multirow[t]{2}{*}{ Source } \\
\hline & & & Clade & 'Type' & & & \\
\hline \multirow{17}{*}{$\begin{array}{r}\text { Plexauridae } \\
\text { (continued) }\end{array}$} & Euplexaura & nuttingi & $\mathrm{G}$ & & $\mathrm{Au}$ & 1 & 18 \\
\hline & \multirow[t]{6}{*}{ Muricea } & atlantica & B & & $\mathrm{Pa}$ & 2 & 2 \\
\hline & & elongata & B & B1 & $\mathrm{Bb}(1), \mathrm{Pa}(1)$ & 2 & 2,21 \\
\hline & & laxa & B & & $\mathrm{Be}(1), \mathrm{Pa}(4)$ & 5 & 2 \\
\hline & & muricata & B & B1 & $\mathrm{Me}(3), \mathrm{Pa}(4)$ & 7 & $2,7,18$ \\
\hline & & uniden & B & & $\mathrm{Pa}$ & 1 & 2 \\
\hline & & sp. & B & B1 & $\mathrm{Bb}(2), \mathrm{Fl}(6)$ & 8 & $9,14,21$ \\
\hline & \multirow[t]{3}{*}{ Muriceopsis } & flavida & $\mathrm{B}$ & & $\mathrm{Me}(1), \mathrm{Pa}(4)$ & 5 & 2,18 \\
\hline & & urabensis & B & & $\mathrm{Pa}$ & 1 & 2 \\
\hline & & spp. & B & & $\mathrm{Ba}(3), \mathrm{Pa}(3)$ & 6 & 2 \\
\hline & \multirow[t]{3}{*}{ Plexaura } & flexuosa & B & B1, B1b & $\begin{array}{c}\mathrm{Ba}(3), \mathrm{Bb}(1), \\
\mathrm{Bz}(1), \mathrm{Fl}(35), \\
\mathrm{Me}(2), \mathrm{Pa}(8)\end{array}$ & 50 & $\begin{array}{c}2,6,7 \\
9,21\end{array}$ \\
\hline & & homomalla & $\mathrm{B}, \mathrm{C}, \mathrm{B} \& \mathrm{C}$ & B1,B1a, C1 & $\begin{array}{l}\mathrm{Ba}(3), \mathrm{Bb}(1), \\
\mathrm{Fl}(2), \mathrm{Me}(3), \\
\mathrm{Pa}(46)\end{array}$ & 55 & $\begin{array}{l}2,6 \\
7,18 \\
19,21\end{array}$ \\
\hline & & kuna & B & B1 & $\begin{array}{l}\text { Ba (25), Bz (1), } \\
\text { Fl (20), Pa (105) } \\
\text { VI (8) }\end{array}$ & 159 & $\begin{array}{c}2,4,5 \\
6,9\end{array}$ \\
\hline & \multirow[t]{4}{*}{ Pseudoplexaura } & flagellosa & B & B1, B8 & $\begin{array}{l}\mathrm{Ba}(2), \mathrm{Be}(1), \\
\mathrm{Fl}(3), \mathrm{Me}(1), \\
\mathrm{Pa}(2)\end{array}$ & 9 & $1,2,7$ \\
\hline & & porosa & B & & $\begin{array}{l}\mathrm{Ba}(1), \mathrm{Be}(1), \\
\mathrm{Bz}(6), \mathrm{Fl}(1), \\
\mathrm{Pa}(7)\end{array}$ & 16 & 1,2 \\
\hline & & wagenaari & B & B1 & $\begin{array}{l}\mathrm{Fl}(2), \mathrm{Me}(2) \\
\mathrm{Pa}(1)\end{array}$ & 5 & $2,7,18$ \\
\hline & & spp. & B & B1, B1L & $\begin{array}{l}\text { Ba (2), Bb (1), } \\
\text { Fl (1), Pa (3), } \\
\text { VI (1) }\end{array}$ & 8 & $2,9,21$ \\
\hline Subergorgiidae & Subergorgia & suberosa & $\mathrm{C}$ & & $\mathrm{Gu}$ & 1 & 1 \\
\hline Tubiporidae & Tubipora & musica & $\mathrm{C}, \mathrm{D}$ & $\mathrm{C} 1 \mathrm{~b}$ & $\mathrm{Au}(3), \mathrm{Is}(1)$ & 4 & $1,12,18$ \\
\hline \multirow[t]{14}{*}{ Xeniidae } & \multirow[t]{3}{*}{ Anthelia } & edmondsoni & $\mathrm{A}$ & & На & 8 & 1 \\
\hline & & glauca & $\mathrm{C}$ & & Is & 3 & 11 \\
\hline & & spp. & $\mathrm{C}$ & C64, C84a & $\mathrm{Au}$ & 4 & $1,3,12$ \\
\hline & Asterospicularia & laurae & $\mathrm{C}$ & C15 & $\mathrm{Au}$ & 2 & 3 \\
\hline & Cespitularia & spp. & $\mathrm{C}$ & $\mathrm{C} 15, \mathrm{C} 1 \mathrm{q}$ & $\mathrm{Au}$ & 9 & $1,3,18$ \\
\hline & Efflatounaria & sp. & $\mathrm{C}$ & $\mathrm{C} 1 \mathrm{c}, \mathrm{C} 1: 3 \mathrm{a}$ & $\mathrm{Au}$ & 7 & 3 \\
\hline & \multirow[t]{2}{*}{ Heteroxenia } & fuscescens & $\mathrm{C}$ & & Is & 13 & 1,11 \\
\hline & & spp. & $\mathrm{C}$ & $\begin{array}{l}\text { C15, C15e, } \\
\text { C64 }\end{array}$ & $\mathrm{Au}$ & 6 & 3,12 \\
\hline & Sarcothelia & sp. & $\mathrm{C}$ & C15b & На & 2 & 13 \\
\hline & Sympodium & sp. & $\mathrm{D}$ & & $\mathrm{Au}$ & 1 & 18 \\
\hline & \multirow[t]{4}{*}{ Xenia } & farauensis & $\mathrm{C}$ & & Is & 3 & 11 \\
\hline & & macrospiculata & $\mathrm{C}$ & & Is & 3 & 11 \\
\hline & & umbellata & $\mathrm{C}$ & & Is & 3 & 11 \\
\hline & & spp. & $\mathrm{C}$ & C1k, C15, C64 & $\mathrm{Au}(17)$, Is (11) & 28 & $\begin{array}{l}1,2,3 \\
17,18\end{array}$ \\
\hline \multicolumn{8}{|c|}{ 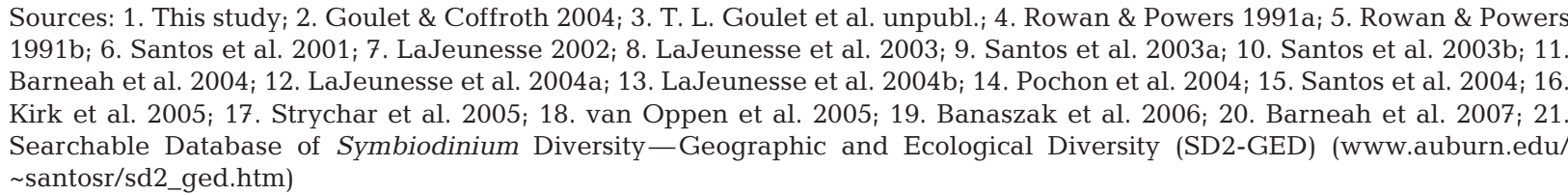 } \\
\hline
\end{tabular}


Table 2. Sampling of octocoral species throughout the tropics. In each geographic area, the number of sites and the number of octocoral genera sampled are given. Total N: total number of colonies sampled in each country

\begin{tabular}{|lrrr|}
\hline Area & No. of sites & No. of genera & Total N \\
\hline Australia & 27 & 31 & 222 \\
Bahamas & 17 & 8 & 812 \\
Barbados & 5 & 9 & 34 \\
Belize & 5 & 5 & 19 \\
Bermuda & 1 & 4 & 5 \\
Fiji & 1 & 5 & 40 \\
Florida Keys & 16 & 9 & 195 \\
Guam & 5 & 6 & 24 \\
Hawaii & 1 & 3 & 17 \\
Israel & 1 & 13 & 112 \\
Japan & 2 & 2 & 3 \\
Mexico & 3 & 11 & 44 \\
Panama & 9 & 11 & 305 \\
Tortugas & 1 & 1 & 8 \\
US Virgin Islands & 2 & 7 & 16 \\
\hline
\end{tabular}

We determined the molecular weight of the RFLP bands by either (1) scanning negatives of the RFLP gels into a computer and using the program NCSA GelReader 2.0.5 (NCSA, University of Illinois) or (2) obtaining and analyzing a digital image of the gel using the KODAK Electrophoresis Documentation and Analysis System (EDAS).

Data analysis. We combined our data with what is currently known in the literature to generate a data set of Symbiodinium clade identities in 117 tropical octocoral species (see references in Table 1). We only used data obtained from field-collected samples and not from zooxanthella cultures. Culturing is highly selective, and the zooxanthellae in culture may not represent the dominant Symbiodinium clade found within a host species (Goulet \& Coffroth 1997, Santos et al. 2001, LaJeunesse 2002). If a report did not specify the sample size, we conservatively assigned an $\mathrm{N}$ of 1 to those data.

If an octocoral was not identified to the species level, we listed the genus and a 'sp.' notation. To be conservative, we did not treat each genus level report as a different species. Instead, we combined these reports, listing all such reports as 'spp.' Such an approach may have underestimated the number of species hosting a single Symbiodinium clade; for example, if in 3 reports about species within a given genus, 2 documented clade $\mathrm{B}$ and 1 documented clade $\mathrm{C}$, we reported this as spp. hosting multiple clades ('B\&C'). Octocorals were classified as hosting multiple Symbiodinium clades if individuals from that octocoral species hosted 2 or more clades either at different depths on the same reef, on different reefs, in different geographic locations, or within the same colony.
When available, we incorporated data on Symbiodinium types within zooxanthella clades. However, Symbiodinium types are distinguished using different parts of the genome: ITS1 and ITS2 (e.g. LaJeunesse 2001), ITS2 (van Oppen et al. 2001), and 23S rDNA of chloroplasts (Santos et al. 2003a). Furthermore, researchers have used different nomenclature for withinclade distinction (LaJeunesse 2001, van Oppen et al. 2001, Santos et al. 2003a). We chose the nomenclature of LaJeunesse (2001), since most biogeographic within-clade data in octocorals use this nomenclature. For 3 types published by other researchers we were able to 'translate' because an equivalent was provided. Type B184 is the same as LaJeunesse type B1 (Kirk et al. 2005). Sub-clade $C 1$ and $C 2$ used by van Oppen et al. (2001) are equivalent to LaJeunesse type C1 and C3i, respectively (LaJeunesse et al. 2003). If we could not identify the type according to LaJeunesse's nomenclature, we did not list it.

GIS data analysis. We entered data in tabular format to create a Geographic Information System (GIS) map using ArcMap (version 8.3, ESRI). The GIS included a world map as the primary base layer. A geographic coordinate system was used for the spatial component of the samples. The latitude and longitude coordinates of the samples were converted to decimal format. The data were plotted to reveal any spatial patterns resulting from clade distributions. Feature map creation of specific octocoral attributes involved querying the main coral database and sub-setting the queried features as an individual layer. Once a sub-layer containing any specific coral attribute was created, these data were then joined with the world map and global reference layer to produce a spatial distribution map. The subset process was repeated for all additional queried features. Within each of the 15 geographic areas, multiple sites were sampled (Table 2). Due to close geographic proximity, for the map presentation (see Figs. 1 $\& 2$ ), we pooled the data from all sites into one geographic location. Since the sites from the Great Barrier Reef (Australia) were from different latitudes, we grouped sites in close proximity, but we still delineated 3 sites within the Great Barrier Reef. Of the 117 octocoral species, 47 species were sampled from more than 1 geographic location enabling latitudinal and longitudinal geographic comparison of Symbiodinium clades in conspecifics.

\section{RESULTS}

By combining our data with those found in other sources, we were able to compare the Symbiodinium clade identity in 117 species of octocorals belonging to 46 genera and 15 families (Fig. 1, Table 1). These octo- 


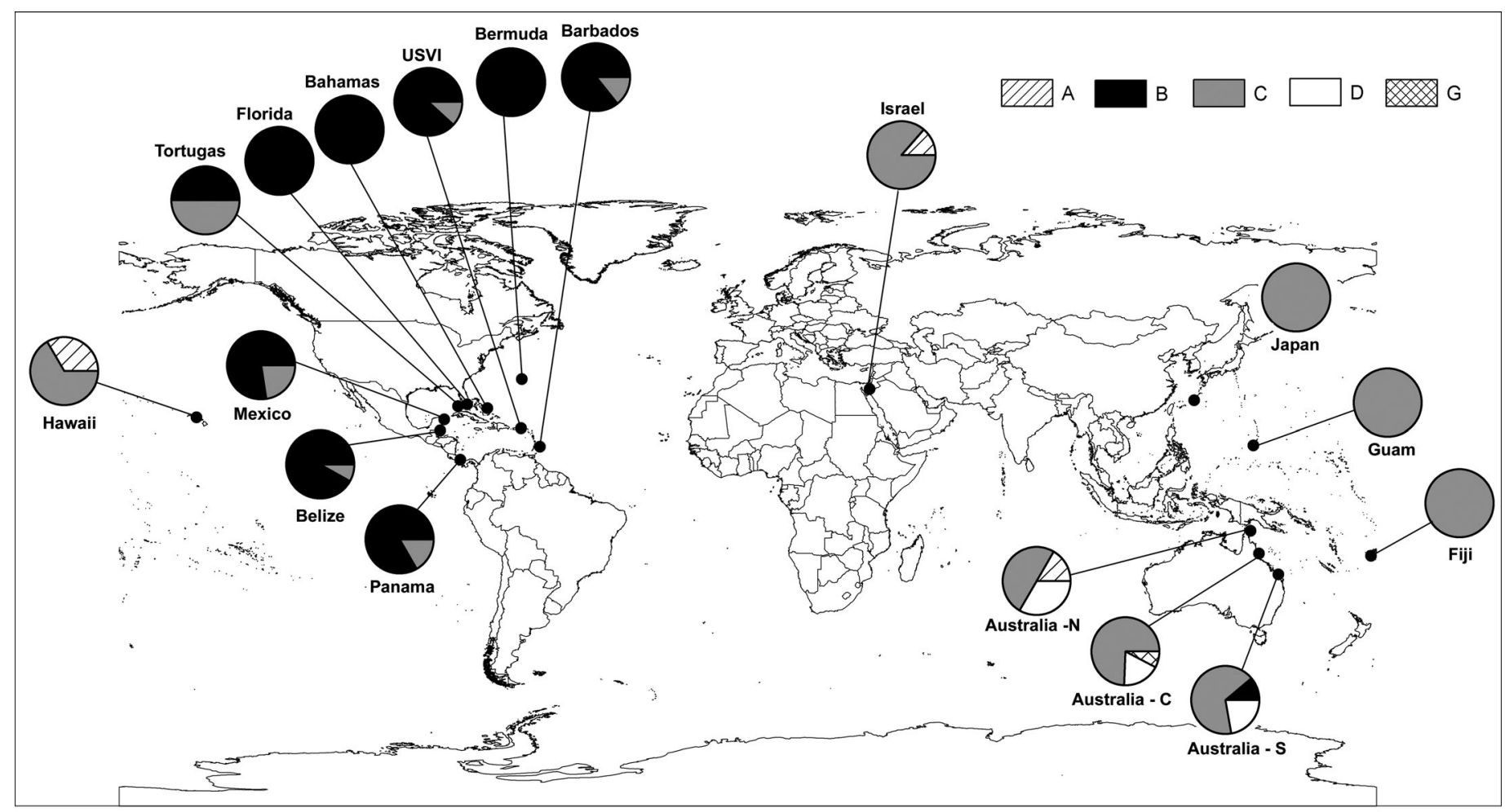

Fig. 1. Global distribution of Symbiodinium clades in tropical octocorals. Pie charts represent the percent of each clade at each geographic location. Number of sites sampled at each geographic location, number of genera sampled, and total number of samples are listed in Table 2. USVI: US Virgin Islands

corals were collected from reefs near 15 locations worldwide (Table 2). Because many of the samples were collected while surveying reefs, sample sizes per species ranged from 1 to 767 (Table 1).

The majority of the octocoral species sampled $(87.2 \%)$ harbored a single detectable Symbiodinium clade (Table 1, Fig. 1). For 63 octocoral species, withinclade data are available using the nomenclature of LaJeunesse (2001; Table 1). In total, 13 Symbiodinium B types were found in octocorals, with type B1 being the dominant type, occurring in 31 of 32 species for which the B type is known. Within Symbiodinium C, 18 types were found in 35 species for which the C type is known. In 15 of these 35 species, Symbiodinium C1 occurred. Only 2 types were reported from clade D (D1a and D3). Of the 15 species that hosted multiple zooxanthella clades, 8 species hosted Symbiodinium B and C, with 3 species hosting Symbiodinium B and C simultaneously within the same colony; 4 species hosted $C$ and $D_{i} 1$ species hosted $C$ and $G_{;} 1$ species hosted A, C, and D; and 1 species hosted zooxanthellae from clades A, B, C, or D.

To determine if cladal specificity occurred at the family level, we compared zooxanthella clades in 5 families in which 10 or more species were sampled. In the family Alcyoniidae, all 23 species sampled hosted Symbiodinium C, with 2 species also hosting Symbiodinium D. For 8 of the species, the Symbiodinium type is known, and some of these types $(\mathrm{C} 3 \mathrm{j}, \mathrm{C} 71 \mathrm{a})$ were found exclusively in the Alcyoniidae. In the family Gorgoniidae, 17 of 21 species hosted Symbiodinium B, with 3 of these also hosting Symbiodinium C. Of these 17 species, within-clade identity is known for 15 species, all of which hosted type B1 with some hosting additional B types (Table 1). The remaining 4 gorgoniid species hosted Symbiodinium C. In the 11 Nephtheidae species, 6 hosted only Symbiodinium C, 2 hosted Symbiodinium A, and 3 hosted multiple zooxanthella clades (A, B, C, D, or G; Table 1). We had within-clade data for 6 Nephtheidae species. Four of these species hosted clade C1:2. In 29 species sampled in the Plexauridae, 25 species hosted only clade B zooxanthellae, and 3 species hosted clades B and C. Euplexaura nittnigi was the only plexaurid sampled from the Indo-west Pacific, and it hosted only clade G (Table 1). Symbiodinium type was known for 14 plexaurid species. All 14 species hosted type B1, and 5 of these had an additional B type. For the 3 species hosting Symbiodinium C, type C1 occurred in all of them. In the 14 Xeniidae species, 12 species hosted Symbio- 


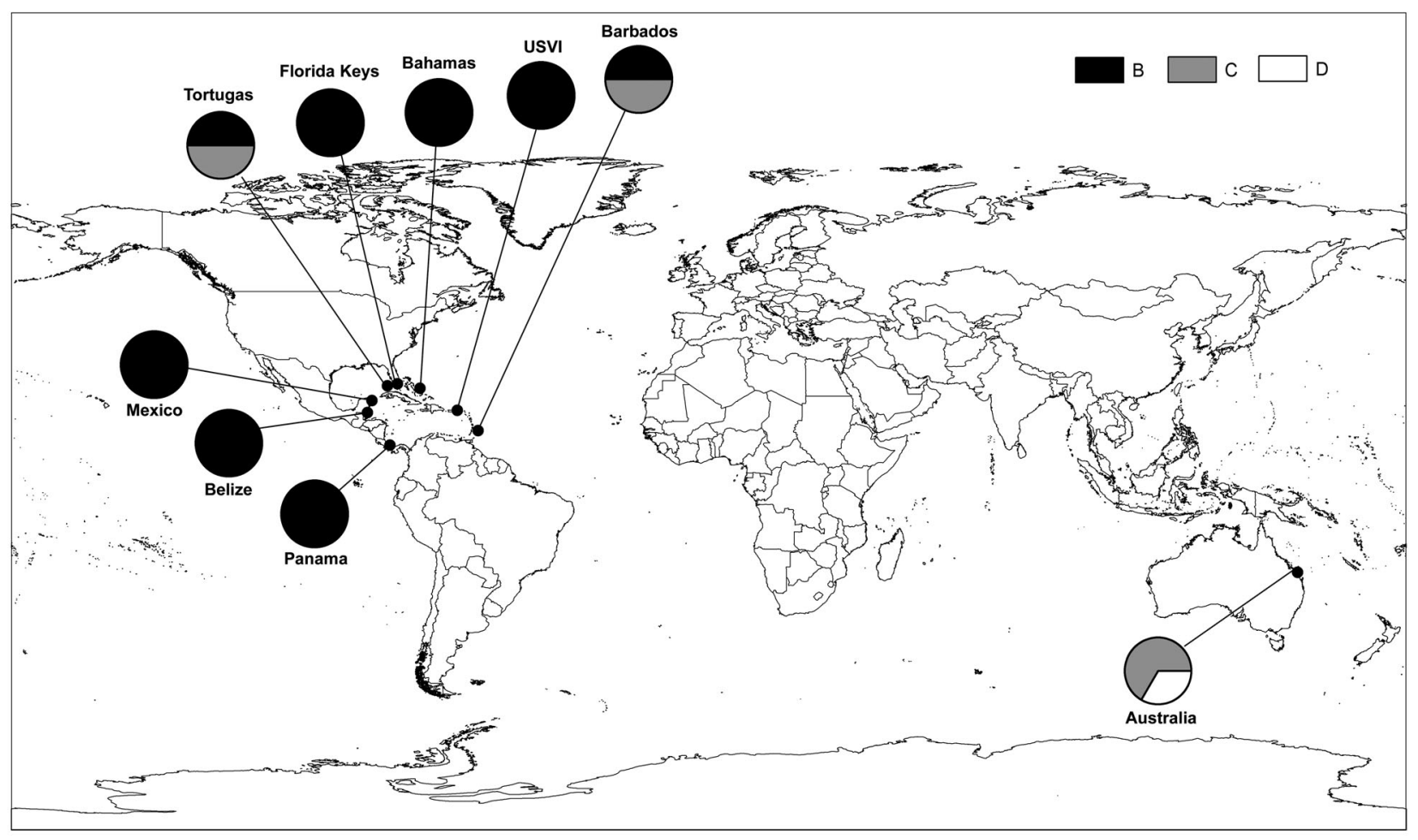

Fig. 2. Distribution of Symbiodinium clades in the family Briaeridae. USVI: US Virgin Islands

dinium C while Anthelia edmondsoni hosted clade A and Sympoidium sp. hosted clade D zooxanthellae (Table 1). Symbiodinium types $\mathrm{C} 1 \mathrm{k}, \mathrm{C} 1 \mathrm{q}$, and $\mathrm{C} 84 \mathrm{a}$ have been reported only from the Xeniidae (LaJeunesse et al. 2004, T. L. Goulet et al. unpubl.).

Comparing zooxanthella clades in octocorals throughout the tropics revealed a bio-geographic pattern (Fig. 1, Table 1). Octocorals in multiple sites in the Indo-west Pacific (Great Barrier Reef [GBR], Guam, Fiji, and Japan), Red Sea (Israel), and Pacific (Hawaii) hosted predominantly clade C zooxanthellae (Fig. 1). Symbiodinium A was found in octocorals sampled from Hawaii, Israel, and the GBR, while Symbiodinium D and $G$ were only found in GBR octocorals (Fig. 1). Octocorals in the Caribbean and Bermuda hosted predominantly Symbiodinium B.

Certain Symbiodinium types were distributed globally while others exhibited a limited distribution (Table 1). Symbiodinium type B1 was very common in octocoral species in Bermuda and the Caribbean for which type data are available. Symbiodinium type C1 and $\mathrm{C} 3$ were found both in the Caribbean and the Indo-west Pacific, but in the Caribbean these are the only C types, while the Indo-west Pacific has numerous C types.

In total, 47 octocoral species were sampled from 2 or more geographic locations (Table 1). In the majority
$(76.6 \%)$ of these species, conspecifics hosted the same zooxanthella clade in all different geographic locations, both in latitudinal and longitudinal comparisons (Table 1). For example, Sinularia polydactyla hosts Symbiodinium C in Australia, Guam, and Israel. Gorgonia mariae hosts Symbiodinium B, type B1, in the Bahamas, Barbados, Mexico, and Panama. We compared the zooxanthella clades in the family Briareidae from samples obtained in the Caribbean and the Indowest Pacific. We found that Briareidae in the Caribbean hosted predominantly Symbiodinium B $(92.8 \%)$ with only 7 of 98 colonies hosting Symbiodinium $\mathrm{C}$ (Fig. 2). Briareidae colonies sampled in the Indo-west Pacific hosted Symbiodinium C with Briarium stechei only hosting Symbiodinium D (Fig. 2).

\section{DISCUSSION}

Octocorals are an important constituent of many coral reefs, and yet few studies have focused on Symbiodinium clade identity in octocorals (Goulet \& Coffroth 2003a,b, 2004, Santos et al. 2003b, 2004, Barneah et al. 2004, van Oppen et al. 2005). The data compiled in this study enabled a worldwide biogeographic synthesis of Symbiodinium clades in tropical octocoral species. 


\section{Specificity of Symbiodinium clades in octocorals}

Most (87.2\%) of the 117 zooxanthellate octocoral species sampled worldwide hosted a single detectable Symbiodinium clade. Although for some of the octocoral species only small sample sizes are currently available, the samples are probably a true representation of the clades present in these species. This conclusion is based on multiple lines of evidence. First, octocorals hosting multiple clades were identified as such with sample sizes of 2 to 3 individuals (Table 1). This detection concurs with the fact that in scleractinian corals, sample sizes of 5 or less detect $87.5 \%$ of the scleractinian coral species hosting multiple clades (Goulet 2007). Furthermore, increasing sampling effort does not change the finding that the vast majority of octocorals host a single zooxanthella clade (Baker \& Romanski 2007). Second, the clade identity of zooxanthellae in octocoral species is compiled from multiple studies conducted on different reefs and different geographic locations (see Table 1 for references). The vast majority of scleractinian coral species also host a single Symbiodinium clade (LaJeunesse 2002, Baker 2003, Goulet 2006, 2007). Of the $12.8 \%$ of octocoral species that hosted more than 1 zooxanthella clade, only Eunicea clavigera, E. tournerforti, and Plexaura homomalla hosted multiple clades simultaneously within the same colony. Octocorals hosting a single zooxanthella clade may not be able to change that clade even if new environmental conditions arise (Goulet 2006).

Hosting only one Symbiodinium clade demonstrates a degree of specificity. Furthermore, octocoral taxonomic affinity exists between an octocoral family and zooxanthella clade. For example, all 23 species sampled from the family Alcyoniidae, from 6 geographic locations, host Symbiodinium C with 2 species also hosting Symbiodinium D (Table 1). In the 21 species sampled from the Gorgoniidae, 18 species were sampled from up to 5 sites throughout the Caribbean, and 17 of them hosted Symbiodinium B (Table 1). Our results concur with Goulet \& Coffroth's (2004) description of host taxonomic affinity in both octocorals and scleractinian corals within the Caribbean. Specificity may also occur at the sub-cladal level. For example, the Alcyoniidae was the only family to host Symbiodinium type C3j. In scleractinian corals, pocilloporids have the same Symbiodinium type (C1c) throughout their geographic range in the GBR, Hawaii, and eastern Pacific (LaJeunesse et al. 2003).

Cladal specificity in certain species has been attributed to the mode of symbiont transmission. In a study in the Red Sea, all octocoral species that had maternal symbiont transmission of zooxanthellae (brooders with vertical transmission) hosted Symbiodinium A while the species with environmental acquisition (horizontal transmission) hosted Symbiodinium C (Barneah et al. 2004). For 2 of the 3 genera that brood, Nephthea and Stereonephthya, we now have clade identity data for samples from the GBR and Fiji. Unlike the samples collected in the Red Sea that only associated with clade A symbionts, Nephthea in the GBR hosts Symbiodinium B, C, or D (van Oppen et al. 2005, T. L. Goulet et al. unpubl.), and Stereonephthya hosts Symbiodinium C or G in the GBR (van Oppen et al. 2005, T. L. Goulet et al. unpubl.) and Symbiodinium C in Fiji (current study). Mode of transmission may therefore not explain specific Symbiodinium in octocorals. Lack of correlation between transmission mode and zooxanthellae was also observed in Montipora spp. and Acropora spp. in Australia and Indonesia (van Oppen 2004).

\section{Biogeography of Symbiodinium clades in octocorals}

Zooxanthellae in octocorals exhibit a worldwide biogeographic pattern. For example, octocorals from the Indo-west Pacific hosted predominantly clade $\mathrm{C}$, which is also the dominant clade in scleractinian corals of that region (LaJeunesse et al. 2004a). In octocorals, the GBR displayed the highest Symbiodinium variability (A, B, C, D, and G) compared to anywhere else currently sampled in the Indo-west Pacific. In Fiji, Guam, and Japan, octocorals hosted only clade C (Fig. 1, Table 1). Rodriguez-Lanetty et al. (2001) also found higher cladal variability in Australian samples of the scleractinian coral Plesiastrea versipora.

Symbiodinium A zooxanthellae occurred in 1 octocoral species in the GBR (van Oppen et al. 2005). Clade A also associated with 3 octocoral species sampled in the Red Sea (Barneah et al. 2004, this study). In Hawaii, Symbiodinium A occurs in 1 octocoral species (LaJeunesse et al. 2004b, this study) out of the 4 zooxanthellate octocoral species (Fabricius \& Alderslade 2001). In the GBR, Symbiodinium B was represented in 1 species, and Symbiodinium G was found in 3 octocoral species that have previously been assumed to be azooxanthellate (van Oppen et al. 2005).

Based on octocoral samples collected from the GBR, van Oppen et al. (2005) concluded that Symbiodinium $\mathrm{D}$ is a common clade in octocorals in the Indo-west Pacific. Some types of Symbiodinium D have been implicated as being 'heat tolerant' (Rowan 2004, Berkelmans \& van Oppen 2006, LaJeunesse et al. 2007) and therefore of potential importance during climate change. The current study shows that although clade D zooxanthellae occur in $24.4 \%$ of GBR octocorals (11 of 45 species sampled), it has not been documented in octocorals in the other 4 sites sampled in the Indo-west Pacific and the Red Sea. Furthermore, in a study conducted during a bleaching event in the GBR, 
bleached and unbleached colonies of octocoral species hosted the same Symbiodinium clade and types within a clade, and Symbiodinium type did not explain bleaching susceptibility among species (T. L. Goulet et al. unpubl.). In octocorals, therefore, species survivorship in changing environmental conditions may rely on aspects of the symbioses other than the zooxanthella clade present. For example, bleaching susceptibility may be a consequence of differences in host tolerance (Loya et al. 2001, Brown et al. 2002, Bhagooli \& Hidaka 2004)

Similar to octocorals in the Indo-west Pacific, 1 Symbiodinium clade was most prevalent in Caribbean octocorals. Unlike in the Indo-west Pacific where octocorals hosted predominantly clade $\mathrm{C}$, the majority of the 48 Caribbean octocoral species and all Bermuda octocorals hosted clade B zooxanthellae. In the Caribbean, most octocorals $(83.3 \%)$ exclusively hosted clade B while 8 species hosted clade $B$, clade $C$, or both simultaneously. In the Caribbean, only 1 of the octocoral species sampled, Plexaurella dichotoma, hosted Symbiodinium $\mathrm{C}$ exclusively. In contrast, the dominant Symbiodinium clade of scleractinian corals in the Caribbean is clade C (see Goulet \& Coffroth 2004 for references). In addition, Caribbean scleractinians host clades $\mathrm{A}$ and $\mathrm{D}$, neither of which has been documented in Caribbean octocorals. The occurrence of clade A and B zooxanthellae in the Caribbean may have evolved in the Plio-Pleistocene transition (3.5 to 1.5 million years ago) when cooler temperatures and increased seasonality may have occurred (Baker 2003, LaJeunesse et al. 2003). Why clade B became the dominant clade in octocorals, and clade A is not found at all within Caribbean octocorals, remains to be determined.

Corals found over a wide geographic range, either latitudinal or longitudinal, may host different zooxanthella clades over their range, aiding survival in the different environments (LaJeunesse \& Trench 2000, Loh et al. 2001, Rodriguez-Lanetty et al. 2001). Our study includes data on the Symbiodinium clade(s) in 7 octocoral species across a latitudinal range in the West-Pacific. Most of these octocorals (5 of 7) did not display a latitudinal difference in zooxanthellae, hosting only Symbiodinium C from samples as far apart as Japan and Australia. On the other hand, the genus Stereonephthya hosted Symbiodinium C and G in Australia, Symbiodinium C to the north in Fiji, and Symbiodinium A in the Red Sea. The scleractinian coral Plesiastrea versipora also exhibits variability in Australian samples, hosting Symbiodinium B and C (Rodriguez-Lanetty et al. 2001) although it only hosts Symbiodinium C in Japan (Rodriguez-Lanetty \& Hoegh-Guldberg 2003).

Our study also included longitudinal data on 10 octocoral species that were sampled both in the Red Sea
(Israel) and in the GBR, Fiji, or Guam. Eight of the species hosted only Symbiodinium C across this wide range. The exceptions were Nephthea spp., which hosted clade A in the Red Sea and Symbiodinium B, C, and D in the GBR, and Tubipora musica, which hosted clade C in the Red Sea and Symbiodinium C and D in the GBR. Longitudinal variability has been reported for the zoanthid Palythoa caesia, which hosts only Symbiodinium $\mathrm{C}$ in the west of the Indian Ocean, while in the eastern Indian Ocean it occurs with either Symbiodinium C or D (Burnett 2002).

\section{Symbiodinium types in octocorals}

At the sub-clade level, some Symbiodinium types were widespread while others were confined to a specific geographic location. Symbiodinium types C1 and C3 inhabited octocorals in the Caribbean and Indowest Pacific. Types $\mathrm{C} 1$ and $\mathrm{C} 3$ also associate with multiple scleractinian coral species on reefs in the Caribbean and Indo-west Pacific (LaJeunesse 2002, LaJeunesse et al. 2003, 2004a) and are considered to be generalists and ancestral to other, more specialized, C types (LaJeunesse et al. 2003, 2004a, LaJeunesse 2004). B1 was ubiquitous throughout the Caribbean and Bermuda in octocorals, while the other B types were restricted to particular octocoral species (LaJeunesse 2002, 2004). Certain scleractinian coral species also form symbioses with highly specific Symbiodinium types (LaJeunesse et al. 2003, 2004a).

Although there are more scleractinian coral species in the Indo-Pacific compared to the Caribbean, the diversity of Symbiodinium types is higher in the Caribbean compared to the Indo-Pacific (LaJeunesse et al. 2003, 2004a). In octocorals, as in soritid foraminiferans (Pochon et al. 2004), this is not the case. The symbioses of Caribbean octocorals is dominated by types $\mathrm{B} 1$ and $\mathrm{C} 1$ (for the few $\mathrm{C}$ symbioses). In the Indo-west Pacific, there are many $\mathrm{C}$ types in symbioses with octocorals. Why octocorals differ from scleractinian corals requires further investigation and may prove pivotal in differential survivorship as climate change continues.

\section{Taxonomic versus geographic differences in Symbiodinium clades in octocorals}

Differences in zooxanthella clades found in octocorals in the different geographic locations may be a result of geographic or taxonomic differences. It is difficult to uncouple the two, since taxonomically different hosts exist in the different major geographic areas. In the Caribbean, 2 families (Plexauridae and Gorgoniidae) dominate (Sánchez et al. 2003), whereas in the 
Indo-Pacific, 23 different families occur (Fabricius \& Alderslade 2001). The geographic difference in octocoral family diversity may explain the difference in Symbiodinium clade and type diversity in octocorals from these areas (van Oppen et al. 2005).

Very few species are cosmopolitan, making global comparisons difficult. The family Briareidae is represented from 8 locations in the Caribbean, and from the GBR in the Indo-west Pacific (Fig. 2). Briareids are capable of associating with Symbiodinium C in both oceans, but the proportion of colonies that do so differ between the oceans. The majority of Briareidae sampled in the Caribbean hosted Symbiodinium B $(92.8 \%)$, while in the GBR they hosted Symbiodinium $\mathrm{C}$ and D (Fig. 2). In addition, the Gorgoniidae in the Caribbean hosted only clade B while in Australia they hosted only clade C. On the other hand, Anthothelidae associated with Symbiodinium C in the Caribbean and in the GBR even though Symbiodinium C is not a common clade in octocorals in the Caribbean. The 1 representative of the Plexauridae from the Indo-west Pacific, Euplexaura nuttingi sampled in the GBR, was the only plexaurid to host Symbiodinium G. In the Xeniidae, Symbiodinium A was restricted to the 1 species collected from Hawaii. Additional comparisons between cosmopolitan families will aid in determining the influence of geography versus phylogeny in these symbioses.

\section{The importance of Symbiodinium clade-level resolution for understanding cnidarian-algal symbioses}

Using differences in DNA between different Symbiodinium has enabled researchers to address previously inaccessible questions about cnidarian-zooxanthella symbioses. These questions are from broad biogeographic analyses (e.g. this study) to differences between individual Symbiodinium genotypes (Goulet \& Coffroth 2003a,b) with the full range of resolution in between. For every level, there are appropriate molecular techniques, with new techniques being adopted and modified. Differences in DNA encoding for the ssRNA categorized Symbiodinium into clades (Rowan \& Powers 1991a). Other parts of the genome such as lsRNA (Baker \& Rowan 1997, Pochon et al. 2004), the 23S rDNA of chloroplasts (Santos et al. 2002, Pochon et al. 2006), psbA minicircle (Barbrook et al. 2006), and mitochondrial sequences (Takabayashi et al. 2004) have confirmed the clade distinction.

Attempts have been made to find clade-level physiological differences between Symbiodinium. Comparison of Symbiodinium physiology within a clade from different host species revealed as much variability within a clade as between clades (Savage et al. 2002, Tchernov et al. 2004). On the other hand, if 2 different Symbiodinium clades are compared within the same host species, physiological differences emerge. For example, clade D zooxanthellae are more tolerant of elevated seawater temperatures and/or irradiance compared to clade $\mathrm{C}$ zooxanthellae in the scleractinian corals Pocillopora spp. (Rowan 2004, LaJeunesse et al. 2007) and Acropora millepora (Berkelmans \& van Oppen 2006). Clade A zooxanthellae withstand elevated seawater temperatures better than clade B zooxanthellae in the sea anemone Aiptasia pallida (Goulet et al. 2005). Juveniles of the scleractinian corals Acropora millepora and $A$. tenuis grow at different rates if they are inhabited by clade C or D (Little et al. 2004). Therefore, although it appears that one cannot generalize about physiologies of Symbiodinium within a given clade, in a particular host-symbiont genotypic combination, the physiology differs depending on the zooxanthella clade involved (Goulet et al. 2005).

The ability to change symbionts has also been documented at the clade level. Cnidarians that are capable of hosting multiple zooxanthella clades may, in response to environmental conditions, change the proportion of each clade (symbiont shuffling). For example, Acropora millepora shuffles between clades $\mathrm{C}$ and D (Berkelmans \& van Oppen 2006). The use of new molecular techniques such as real-time PCR has increased our detection of clades within cnidarian species capable of hosting multiple clades (Mieog et al. 2007). It still remains to be determined whether cells detected using molecular techniques are identifying zooxanthellae in symbiosis, or zooxanthella contaminants found externally and/or not in symbiosis (Loram et al. 2007). The clade-level resolution, although broad, provides important information on cnidarianzooxanthella symbioses. However, the examples above deal with scleractinian corals and sea anemones pointing to the paucity of data on octocorals. The current study contributes to our knowledge of zooxanthella clades in octocorals by addressing the fundamental question of zooxanthella clade identity in octocorals in different geographic locations.

\section{CONCLUSIONS}

Understanding the symbioses between octocorals and zooxanthellae is crucial to understanding coral reefs. Octocorals associate with 5 Symbiodinium clades (A, B, C, D, and G) while clade F found in scleractinians (Baker 2003) has not been documented in octocorals to date. In the Indo-west Pacific, Red Sea, and Hawaii, octocoral species predominantly associate with Symbiodinium C, which is also the dominant 
zooxanthella clade in Indo-west Pacific scleractinian corals. In the Caribbean and Bermuda, octocorals predominantly associate with Symbiodinium B, which is not the dominant clade found in scleractinian corals. Deciphering similarities and differences between the symbioses of octocorals and scleractinian corals and their zooxanthellae may aid in predicting coral species survivorship vis-à-vis global climate change.

Acknowledgements. We are indebted to K. Asoh, Y. Benayahu, D. Brazeau, M. A. Coffroth, K. E. Fabricius, H. R. Lasker, S. McKenna, and T. Yoshikawa for providing us with samples. We thank the Interuniversity Institute of Eilat, Israel, for allowing us to use their facility. T. C. LaJeunesse, S. Threlkeld, and 3 anonymous reviewers provided valuable comments on the manuscript. Initial data collection was accomplished with the support of a Grant for Interdisciplinary Graduate Research in Evolutionary Biology and Ecology SUNY Buffalo (T.L.G.). This publication was made possible through support provided by the College of Liberal Arts, the University of Mississippi (T.L.G.), and the National Aeronautics and Space Administration (NASA) to the University of Mississippi (T.L.G.) under the terms of Cooperative Agreement No. NCC5-574 and NASA grant NAG13-02052, for support of the University of Mississippi Geoinformatics Center. The opinions expressed herein are those of the authors and do not necessarily reflect the views of NASA or the University of Mississippi.

\section{LITERATURE CITED}

Baillie BK, Belda BCA, Silvestre V, Sison M, Gomez AV, Gomez ED, Monje V (2000) Genetic variation in Symbiodinium isolates from giant clams based on randomamplified-polymorphic DNA (RAPD) patterns. Mar Biol 136:829-836

Baker AC (2003) Flexibility and specificity in coral-algal symbiosis: diversity, ecology, and biogeography of Symbiodinium. Annu Rev Ecol Syst 34:661-689

Baker AC, Romanski AM (2007) Multiple symbiotic partnerships are common in scleractinian corals, but not in octocorals: Comment on Goulet (2006). Mar Ecol Prog Ser 335: 237-242

Baker AC, Rowan R (1997) Diversity of symbiotic dinoflagellates (zooxanthellae) in scleractinian corals of the Caribbean and Eastern Pacific. Proc 8th Int Coral Reef Symp, Panama 2:1301-1306

Banaszak AT, Santos MG, LaJeunesse TC, Lesser MP (2006) The distribution of mycosporine-like amino acids (MAAs) and the phylogenetic identity of symbiotic dinoflagellates in cnidarian hosts from the Mexican Caribbean. J Exp Mar Biol Ecol 337:131-146

Barbrook AC, Visram S, Douglas AE, Howe CJ (2006) Molecular diversity of dinoflagellate symbionts of Cnidaria: the psbA minicircle of Symbiodinium. Protist 157:159-171

Barneah O, Weis VM, Perez S, Benayahu Y (2004) Diversity of dinoflagellate symbionts in Red Sea soft corals: mode of symbiont acquisition matters. Mar Ecol Prog Ser 275: 89-95

Barneah O, Brickner I, Hooge M, Weis VM, LaJeunesse TC, Benayahu Y (2007) Three party symbiosis: acoelomorph worms, corals and unicellular algal symbionts in Eilat (Red Sea). Mar Biol 151:1215-1223
Berkelmans R, van Oppen MJH (2006) The role of zooxanthellae in the thermal tolerance of corals: a 'nugget of hope' for coral reefs in an era of climate change. Proc R Soc Lond B 273:2305-2312

Bhagooli R, Hidaka M (2004) Photoinhibition, bleaching susceptibility and mortality in two scleractinian corals, Platygyra ryukyuensis and Stylophora pistillata, in response to thermal and light stresses. Comp Biochem Physiol A 137: 547-555

Blank RJ (1987) Cell architecture of the dinoflagellate Symbiodinium sp. inhabiting the Hawaiian stony coral Montipora verrucosa. Mar Biol 94:143-155

Brown BE, Downs CA, Dunne RP, Gibb SW (2002) Exploring the basis of thermotolerance in the reef coral Goniastrea aspera. Mar Ecol Prog Ser 242:119-129

Burnett WJ (2002) Longitudinal variation in algal symbionts (zooxanthellae) from the Indian Ocean zoanthid Palythoa caesia. Mar Ecol Prog Ser 234:105-109

Coffroth MA, Santos SR, Goulet TL (2001) Early ontogenetic expression of specificity in a cnidarian-algal symbiosis. Mar Ecol Prog Ser 222:85-96

Fabricius K, Alderslade P (2001) Soft corals and sea fans: a comprehensive guide to the tropical shallow water genera of the central-west Pacific, the Indian Ocean and the Red Sea. Australian Institute of Marine Science, Townsville

Goldberg WM (1973) The ecology of the coral-octocoral communities off the southeast Florida coast: geomorphology, species composition, and zonation. Bull Mar Sci 23: 465-488

Goulet TL (2006) Most corals may not change their symbionts. Mar Ecol Prog Ser 321:1-7

Goulet TL (2007) Most scleractinian corals and octocorals host a single symbiotic zooxanthella clade. Mar Ecol Prog Ser 335:243-248

Goulet TL, Coffroth MA (1997) A within colony comparison of zooxanthellae genotypes in the Caribbean gorgonian Plexaura kuna. Proc 8th Int Coral Reef Symp, Panama 2: $1331-1334$

Goulet TL, Coffroth MA (2003a) Genetic composition of zooxanthellae between and within colonies of the octocoral Plexaura kuna, based on small subunit rDNA and multilocus DNA fingerprinting. Mar Biol 142:233-239

Goulet TL, Coffroth MA (2003b) Stability of an octocoralalgal symbiosis over time and space. Mar Ecol Prog Ser 250:117-124

Goulet TL, Coffroth MA (2004) The genetic identity of dinoflagellate symbionts in Caribbean octocorals. Coral Reefs 23:465-472

Goulet TL, Cook CB, Goulet D (2005) Effects of short-term exposure to elevated temperatures and light levels on photosynthesis of different host-symbiont combinations in the Aiptasia pallida / Symbiodinium symbiosis. Limnol Oceanogr 50:1490-1498

Kinzie RA III (1973) The zonation of West Indian gorgonians. Bull Mar Sci 23:93-154

Kinzie RA III (1974) Plexaura homomalla: the biology and ecology of a harvestable marine resource. Stud Trop Oceanogr 12:22-28

Kinzie RA III, Chee GS (1982) Strain-specific differences in surface antigens of symbiotic algae. Appl Environ Microbiol 44:1238-1240

Kirk NL, Ward JR, Coffroth MA (2005) Stable Symbiodinium composition in the sea fan Gorgonia ventalina during temperature and disease stress. Biol Bull (Woods Hole) 209: 227-234

LaJeunesse TC (2001) Investigating the biodiversity, ecology, and phylogeny of endosymbiotic dinoflagellates in the 
genus Symbiodinium using the ITS region: in search of a 'species' level marker. J Phycol 37:866-880

LaJeunesse TC (2002) Diversity and community structure of symbiotic dinoflagellates from Caribbean coral reefs. Mar Biol 141:387-400

LaJeunesse TC (2004) 'Species' radiations of symbiotic dinoflagellates in the Atlantic and Indo-Pacific since the Miocene-Pliocene transition. Mol Biol Evol 22:570-581

LaJeunesse TC, Trench RK (2000) Biogeography of two species of Symbiodinium (Freudenthal) inhabiting the intertidal sea anemone Anthopleura elegantissima (Brandt). Biol Bull (Woods Hole) 199:126-134

LaJeunesse TC, Loh W, van Woesik R, Hoegh-Guldberg O, Schmidt GW, Fitt WK (2003) Low symbiont diversity in southern Great Barrier Reef corals, relative to those of the Caribbean. Limnol Oceanogr 48:2046-2054

LaJeunesse TC, Bhagooli R, Hidaka M, DeVantier L and others (2004a) Closely related Symbiodinium spp. differ in relative dominance in coral reef host communities across environmental, latitudinal and biogeographic gradients. Mar Ecol Prog Ser 284:147-161

LaJeunesse TC, Thornhill DJ, Cox EF, Stanton FG, Fitt WK, Schmidt GW (2004b) High diversity and host specificity observed among symbiotic dinoflagellates in reef coral communities from Hawaii. Coral Reefs 23:596-603

LaJeunesse TC, Reyes-Bonilla H, Warner ME (2007) Spring 'bleaching' among Pocillopora in the Sea of Cortez, Eastern Pacific. Coral Reefs 26:265-270

Lasker HR, Coffroth MA (1983) Octocoral distributions at Carrie Bow Cay, Belize. Mar Ecol Prog Ser 13:21-28

Little AF, van Oppen MJH, Willis BL (2004) Flexibility in algal endosymbioses shapes growth in reef corals. Science 304: 1492-1494

Loh WKW, Loi T, Carter D, Hoegh-Guldberg O (2001) Genetic variability of the symbiotic dinoflagellates from the wide ranging coral species Seriatopora hystrix and Acropora longicyathus in the Indo-West Pacific. Mar Ecol Prog Ser 222:97-107

Loram JE, Boonham N, O'Toole P, Trapido-Rosenthal HG, Douglas AE (2007) Molecular quantification of symbiotic dinoflagellate algae of the genus Symbiodinium. Biol Bull (Woods Hole) 212:259-268

Loya Y, Sakai K, Yamazato K, Nakano Y, Sambali H, van Woesik R (2001) Coral bleaching: the winners and the losers. Ecol Lett 4:122-131

Magalon H, Baudry E, Huste A, Adjeroud M, Veuille M (2006) High genetic diversity of the symbiotic dinoflagellates in the coral Pocillopora meandrina from the South Pacific. Mar Biol 148:913-922

Mieog JC, van Oppen MJH, Cantin NE, Stam WT, Olsen JL (2007) Real-time PCR reveals a high incidence of Symbiodinium clade D at low levels in four scleractinian corals across the Great Barrier Reef: implications for symbiont shuffling. Coral Reefs 26:449-457

Muzik K (1982) Octocorallia (Cnidaria) from Carrie Bow Cay, Belize. Smithson Contrib Mar Sci 12:303-310

Pochon X, LaJeunesse TC, Pawlowski J (2004) Biogeographic partitioning and host specialization among foraminiferan dinoflagellate symbionts (Symbiodinium; Dinophyta). Mar Biol 146:17-27

Pochon X, Montoya-Burgos JI, Stadelmann B, Pawlowski J (2006) Molecular phylogeny, evolutionary rates, and divergence timing of the symbiotic dinoflagellate genus Symbiodinium. Mol Phylogen Evol 38:20-30

Rodriguez-Lanetty M, Hoegh-Guldberg O (2003) Symbiont diversity within the widespread scleractinian coral Plesiastrea versipora, across the northwestern Pacific. Mar Biol
143:501-509

Rodriguez-Lanetty M, Loh WKW, Carter D, Hoegh-Guldberg O (2001) Latitudinal variability in symbiont specificity within the widespread scleractinian coral Plesiastrea versipora. Mar Biol 138:1175-1181

Rowan R (1998) Diversity and ecology of zooxanthellae on coral reefs. J Phycol 34:407-417

Rowan R (2004) Coral bleaching: thermal adaptation in reef coral symbionts. Nature 430:742

Rowan R, Powers DA (1991a) A molecular genetic classification of zooxanthellae and the evolution of animal-algal symbiosis. Science 251:1348-1351

Rowan R, Powers DA (1991b) Molecular genetic identification of symbiotic dinoflagellates (zooxanthellae). Mar Ecol Prog Ser 71:65-73

Sánchez JA, Diaz JM, Zea S (1997) Gorgonian communities in two contrasting environments on oceanic atolls of the Southwestern Caribbean. Bull Mar Sci 61:453-465

Sánchez JA, McFadden CS, France SC, Lasker HR (2003) Molecular phylogenetic analyses of shallow-water Caribbean octocorals. Mar Biol 142:975-987

Santos SR, Taylor DJ, Coffroth MA (2001) Genetic comparisons of freshly isolated versus cultured symbiotic dinoflagellates: implications for extrapolating to the intact symbiosis. J Phycol 37:900-912

Santos SR, Taylor DJ, Kinzie RAI, Hidaka M, Sakai K, Coffroth MA (2002) Molecular phylogeny of symbiotic dinoflagellates inferred from partial chloroplast large subunit (23S)-rDNA sequences. Mol Phylogenet Evol 23: $97-111$

Santos SR, Gutierrez-Rodriguez C, Coffroth MA (2003a) Phylogenetic identification of symbiotic dinoflagellates via length heteroplasmy in domain $\mathrm{V}$ of chloroplast large subunit (cp23S)-ribosomal DNA sequences. Mar Biotechnol 5: $1-11$

Santos SR, Gutiérrez-Rodríguez C, Coffroth MA (2003b) Symbiodinim sp. associations in the gorgonian Pseudopterogorgia elisabethae in the Bahamas: high levels of genetic variability and population structure in symbiotic dinoflagellates. Mar Biol 143:111-120

Santos SR, Shearer TL, Hannes AR, Coffroth MA (2004) Finescale diversity and specificity in the most prevalent lineage of symbiotic dinoflagellates (Symbiodinium, Dinophyceae) of the Caribbean. Mol Ecol 13:459-469

Savage AM, Trapido-Rosenthal H, Douglas AE (2002) On the functional significance of molecular variation in Symbiodinium, the symbiotic algae of Cnidaria: photosynthetic response to irradiance. Mar Ecol Prog Ser 244:27-37

Stat M, Carter D, Hoegh-Guldberg O (2006) The evolutionary history of Symbiodinium and scleractinian hostssymbiosis, diversity, and the effect of climate change. Perspect Plant Ecol Evol Syst 8:23-43

Strychar KB, Coates M, Sammmarco PW, Piva TJ (2005) Loss of Symbiodinium from bleached soft corals Sarcophyton ehrenbergi, Sinularia sp. and Xenia sp. J Exp Mar Biol Ecol 320:159-177

Takabayashi M, Santos SR, Cook CB (2004) Mitochondrial DNA phylogeny of the symbiotic dinoflagellates (Symbiodinium, Dinophyta). J Phycol 40:160-164

Tchernov D, Gorbunov MV, de Vargas C, Yadav SN, Milligan AJ, Häggblom M, Falkowski PG (2004) Membrane lipids of symbiotic algae are diagnostic of sensitivity to thermal bleaching in corals. Proc Natl Acad Sci USA 101: 13531-13535

Trench RK (1997) Diversity of symbiotic dinoflagellates and the evolution of microalgal-invertebrate symbioses. Proc 8th Int Coral Reef Symp, Panama 2:1275-1286 
van Oppen MJH (2004) Mode of zooxanthella transmission does not affect zooxanthella diversity in acroporid corals. Mar Biol 144:1-7

van Oppen MJH, Palstra FP, Piquet AMT, Miller DJ (2001) Patterns of coral-dinoflagellate associations in Acropora: significance of local availability and physiology of Sym-

Editorial responsibility: Otto Kinne,

Oldendorf/Luhe, Germany biodinium strains and host-symbiont selectivity. Proc R Soc Lond B 268:1759-1767

van Oppen MJH, Mieog JC, Sánchez CA, Fabricius KE (2005) Diversity of algal endosymbionts (zooxanthellae) in octocorals: the roles of geography and host relationships. Mol Ecol 14:2403-2417

Submitted: May 23, 2007; Accepted: August 17, 2007

Proofs received from author(s): February 2, 2008 